\title{
Habitat use during post-pre-breeding period in a Rock Sparrow Petronia petronia population
}

\author{
Bruno Santucci ${ }^{1}$, Andrea Pulvirenti ${ }^{2}$, Samuele Ramellini ${ }^{3 *}$, \\ Marinella Miglio ${ }^{1}$
}

\begin{abstract}
Most studies focusing on Rock Sparrow populations concern their breeding biology. With this study, we aim to investigate the wintering habitat and social behaviour outside the breeding period. In the study area the species is present all year long, and, outside the breeding period, birds frequently gather together on flocks of different size (3-150 individuals), which are larger in the coldest months. The habitat types most used by the species were cereal fields with crops in their first stage of development $(17.71 \% \pm 4.72$ Standard Deviation) and arable stubbles, both of them with bushes and trees on their boundaries $(82.4 \%)$, which likely provide shelters from predators. The bird species most frequently associated with Rock Sparrow flocks were Tree Sparrow, Starling and Crested Lark. Holes in the roof tiles of the same abandoned buildings used for breeding were also used as night shelters. The average hours of leaving and returning to the shelters was strictly related to the photoperiod $\left(r_{s}=-0.9405 ; 0.8810\right)$.
\end{abstract}

Key words: Rock Sparrow, Petronia petronia, post breeding period, central Italy.

Riassunto - Uso dell'habitat durante il periodo pre- e post-riproduttivo in una popolazione di Passera lagia Petronia petronia.

La maggior parte degli studi sulla Passera lagia riguardano la sua biologia riproduttiva. Lo scopo di questo studio è indagare habitat di svernamento e comportamenti al di fuori del periodo riproduttivo. Nell'area di studio la specie è presente tutto l'anno e, al di fuori del periodo riproduttivo, tende a formare gruppi di diverse dimensioni (da 3 a 150 individui), più grandi durante i mesi più freddi. Gli ambienti più utilizzati sono le colture cerealicole nelle prime fasi di sviluppo $(17,71 \% \pm 4,72$ Deviazione Standard) e i campi di stoppie, entrambi con presenza di alberi e cespugli $(82,4 \%)$ posti ai margini, utili come rifugi in caso di attacchi da parte di predatori. Le tre specie di uccelli osservate maggiormente associate ai gruppi in alimentazione sono state la Passera mattugia, lo Storno e la Cappellaccia. I buchi nei laterizi degli stessi edifici abbandonati usati per la nidificazione vengono utilizzati come ricoveri notturni. L'orario di entrata e di uscita dai ricoveri è strettamente legato al fotoperiodo $\left(r_{s}=-0,9405 ; 0,8810\right)$.

Parole chiave: Passera lagia, Petronia petronia, periodo non riproduttivo, Italia centrale.

\footnotetext{
${ }^{1}$ Via Fonte di là 2, 67062 Rosciolo di Magliano dei Marsi (AQ), Italia.

${ }^{2}$ Via Veturia 44, 00181 Roma, Italia.

${ }^{3}$ Dipartimento di Scienze e Politiche Ambientali, Università degli Studi di Milano, Via Celoria 26, 20133 Milano, Italia.

${ }^{*}$ Corresponding author: samuele.ramellini@gmail.com

(C) 2020 Bruno Santucci, Andrea Pulvirenti, Samuele Ramellini, Marinella Miglio
}

Received: 28 September 2018

Accepted for publication: 28 January 2019

Online publication: 12 May 2020

\section{INTRODUCTION}

The Rock Sparrow Petronia petronia is a polytypic species with an extremely large range that spans from Canaries and southern Europe (including some Mediterranean islands) to north-western Africa and West, SouthWest, and central Asia (Summers-Smith, 2018; Brichetti \& Fracasso, 2013).

The subspecies occurring in Italy is $P$. p. petronia (Brichetti \& Fracasso, 2013).

The entire European population was estimated in 2017 to number 2,140,000-4,620,000 pairs, with a stable trend (Birdlife International, 2017) and the species is considered not globally threatened (Summers-Smith, 2018) and of Least Concern in the IUCN Red List (BirdLife International, 2018). In Italy it breeds in central and southern regions, with an isolated population in the north-western Alps (Brichetti \& Fracasso, 2013). In Europe, and also on the Tibetan plateau, its complicated breeding biology has been fully investigated (Printemps, 1992; Mingozzi et al., 1994; Tavecchia et al., 2002; Venuto et al., 2005; Baucells \& Abella, 2007; Guelin, 2007; Brugerolle 2009; Li \& Lu, 2012; Navas et al., 2013). Also within our study region (Abruzzo and Latium, central Italy), nesting site selection, nestling diet and breeding biology have been studied (Brunelli et al., 2013; Pulvirenti \& Santucci, 2017; Santucci et al., 2017). On the other side, there are very few data on the wintering habitat and social behaviour outside the breeding period for Rock Sparrows in the Western Palearctic.

\section{STUDY AREA}

The research has been carried out on the foothills of the southern slope of Mount Velino, into the administrative territory of Massa d'Albe municipality (AQ, Central Italy). The area has been divided in two subareas (called respectively $A$ and $B$ ), already used in the previous studies (Santucci et al., 2017). Area A covers $4.5 \mathrm{Km}^{2}$ wide (Lat $42^{\circ} 05 ' 55^{\prime \prime} \mathrm{N}$ - Long $13^{\circ} 24^{\prime} 03$ ”E; altitudinal range: 780-930 m), while B 4.0 $\mathrm{Km}^{2}$ (Lat 42॰06'36" - Long $13^{\circ} 26^{\prime} 24^{\prime \prime} \mathrm{E}$; altitudinal range: $930-1090 \mathrm{~m}$ ). Therefore, the whole study area is $8.5 \mathrm{Km}^{2}$ wide. Both areas are almost flat, with a mean slope of 5\%. The landscape is typical of the central Apennines, with an agro-pastoral system still preserved, even if threatened by urbanisation. The 
climate is Mediterranean with some continental aspects, characterized by limited rainfall during the summer (min. $31.3 \mathrm{~mm}$; max. $63.5 \mathrm{~mm}$ ), with periods without rain in some years (June-August). The mean temperature of the coldest month (January) is $3.1^{\circ} \mathrm{C}$ and snowfall usually occurs between the second half of December and the first half of March, covering the ground for 1-20 days, with a total of 20-60 days during the whole winter (Petriccione, 1993). Water resources are represented by waterholes and temporary rainwater pools.

We specifically focused on the habitat used by our study species.

Area A is approximately covered by $90 \%$ of intensive cultures (Corine Land Cover, IV Level, 2012: code 211), $5 \%$ of other agricultural areas (code 243 and 242), and another $5 \%$ of scattered areas of woods and pastures. Area $\mathrm{B}$, is approximately covered by $80 \%$ intensive cultures (code 211), 11\% sparse grasslands (code 131), and 7\% grasslands (code 321), and $2 \%$ of other scattered urban areas.

The main types of environments used by Rock Sparrow during the post-pre-breeding period are the following ones:

1) Arable crops:

- Cereal crops. Cereal crops are represented by local cultivars of Rye Secale cereale (40\%), Barley Hordeum vulgare $(40 \%)$, Oat Avena sativa (10\%), Wheat Triticum aestivum and Spelt Triticum dicoccum for the remaining $10 \%$. Due to the limited use of biocides, many weeds occur between crop rows. The most common are Papaver rhoeas, P. argemone, Cyanus segetum, Agrostemma githago, Anthemis arvensis, Consolida regalis, Adonis spp., Legousia speculumveneris, Ranunculus arvensis, Asperula arvensis, Fumaria parviflora, Fallopia convolvolus.

- Arable stubble. After the threshing, some species prevail in the arable stubble, like Chenopodium sp., Atriplex sp., Conyza sp., Erigeron annuum, Verbascum spp., as well as cereal plants that grow back thanks to the scattering of seeds during the threshing. Some stubble lands preserve this appearance until the first spring ploughing. Height range of vegetation: 10-50 $\mathrm{cm}$.

- Ploughings. The autumnal sowing is prepared by shallow ploughings between August and November. In spring the ploughings start between the last decade of March and the last of April.

- Fodders. Onobrychis viciifolia (50\%) and Medicago sativa $(40 \%)$ represent the majority of the forage crops. The remaining $10 \%$ is made up of cultivated plants and weeds like Lolium sp, Trifolium incarnatum and Vicia sativa. A lot of commensal species develop also in the fodder, like Tragopogon porrifolius, Sinapis sp., Sisymbrium irio, Bunias erucago, Capsella bursapastoris, Echium plantagineum, Crepis vesicaria, Sonchus asper. At the end of the fodder cycle (4-5 years), they look like dry grassland where Bromus spp., Phleum abmiguum, Silene conica and Sanguisorba minor predominate. The plants of Sainfoin and Lucerne become sporadic and weeds prevail.
2) Fields margin weeds. These plant communities occur along field borders, dirty roads and near the hedges. Their width varies between $50 \mathrm{~cm}$ and $200 \mathrm{~cm}$. The main species are Artemisia absinthyum, Knautia sp., Alliaria petiolata, Geranium pyrenaicum, Erodium cicutarium, Inula conyzae, Melilotus officinalis, Daucus carota and Silene spp.

3) Fallow lands. In fallow lands from 1-3 years after cultivation onwards, sturdy herbs like Verbascum spp., Onopordum illyricum, Stachys germanica subsp. salviifolia, Hypericum perforatum, Conyza sp., Lactuca serriola, Convolvolus arvensis, Rumex sp., Chenopodium album take place.

4) Xerophilous pastures. These kinds of habitat have established on abandoned arable land and they show different stages of their development depending on time elapsed since abandonment. There are two kinds of pastures. The first one is characterized by small shrubs similar to garrigue. The most common shrubs are Cytisus spinescens, Satureja montana, Hyssopus officinalis, Helichrysum italicum, Euphorbia myrsinites, Sideritis italic, Alyssum alyssoides, etc. In the second one the vegetation is dominated by Poaceae like Bromus erectus, B. sterilis, B. gr. hordeaceus, Phleum ambiguum, Stipa dasyvaginata, S. capillata, Avena barbata, Hordeum sp., Dactylis glomerata, Aegilops geniculata, Poa bulbosa and Setaria sp. Plant communities of both kinds of pastures belong to the Phleo ambigui-Bromion erecti formation that in this area is represented by the Saturejo montanaeBrometum erecti association. A great floral diversity is found in pastures: Marrubium incanum, Centaurea deusta, Hypericum perforatum, Tordylium apulum, Cardus spp., Potentilla pedata, Sherardia arvensis, Sanguisorba minor, Crepis sancta, Holosteum umbellatum, Coronilla scorpioides, Seseli tortuosum, Ranunculus illyricus. Since 2006, it has been observed the invasion of the alien species Senecio inaequidens (Pace \& Tammaro, 2006).

5) Terrain without vegetation. In Area A, terrains without vegetation are represented by heaps of pebbles, derived from the levelling and removal of stones, gravel roads and drywalls. In area B there are just a few gravel roads and drywalls. However, a lot of different species of plants grow on the heaps of pebbles: Sedum sexangulare, $S$. hispanicum, $S$. dasyphyllum, Alyssoides utriculata, Asphodeline lutea, Arabis sagittata, A. glabra, Geranium rubrum, Hesperis laciniata, Helleborus foetidus, Vincetoxicum hirundinaria, Reseda lutea, Ceterach officinorum.

6) Trees and bushes. Almost all the trees of the two areas are Almonds Prunus dulcis (about 3000 specimens) derived from ancient planting associated with cereal crops and fodders. Some elder individuals also occur in the xerophilous pastures. This is the most distinctive feature of the agricultural land of the study area. Some species of hard bushes like Prunus mahaleb, Prunus spinosa and Crataegus monogyna have developed on the border of the fields. Stunted shrubs like Juniperus oxycedrus, Rosa spp. and Rubus spp. occur in the pastures. 
7) Others. Farm depots, temporary storage of straw bale and hay-bale, dung heaps and orchards.

\section{METHODS}

This study has been carried out in the period between 2010 and 2017. In order to investigate Rock Sparrow behaviour during the post and pre-breeding period (15 September - 15 May), the following aspects have been analysed: types and use of night shelters, feeding habitats, gregariousness and social behaviour, and association with other species on the feeding ground. We have conducted two types of observations:

1- We selected two sample buildings within the study area, where breeding colonies occurred. We reached them early in the morning before individuals would go out from the shelters, and in the evening before they would come back. In the same way we monitored some cavities in the Almond trees used as nesting sites. Every week during the first year we visited both buildings and the almond's cavities at least twice a day (during the morning and the evening). We observed and recorded the types of shelters and social interactions when the Rock Sparrows go out and come back.

2- We surveyed the study area by walking on farm roads. Each week of the period we carried out a minimum of three visits lasting from 2 to 4 hours. We noted the size of the flocks, social behaviour, associating bird species and any attack by predators. Whenever the exact number of individuals could not be counted, we took into account their mean value (e.g., if 20-30 were estimated, we numbered 25). In the sites where the Rock Sparrow had been observed, we assigned the site to one of the habitat types described above. In order to identify the growth stage of cereals in the fields, we referred to the HGCA guidelines "Cereal growth stages - a guide for crop treatments" (Tottmann et al., 1979). In our study we found growth stage 09 (leaf at coleoptile tip) as well as 15-23 (five leaves unfolded on main shoot, three tillers).

The statistical analyses were carried out using RStudio (RStudio team, 2015) and Excel. The correlations were analysed with a Spearman's rho correlation.

\section{RESULTS \\ Flock size}

The biggest flocks were recorded during the coldest months (Jan-Feb; Fig. 1). In the remaining months, the mean value of individuals showed a fluctuating trend (Fig. 2). The maximum number recorded was 150 individuals in the first decade of January, while the minimum was 3 in the second decade of December. The mean flock size during the entire period was $39.6 \pm 23.0$ (S.D.). As it can be seen in Fig. 3, the mean flock size per month was not related to the flock records during the month $\left(r_{\mathrm{s}}=-0.2\right)$.

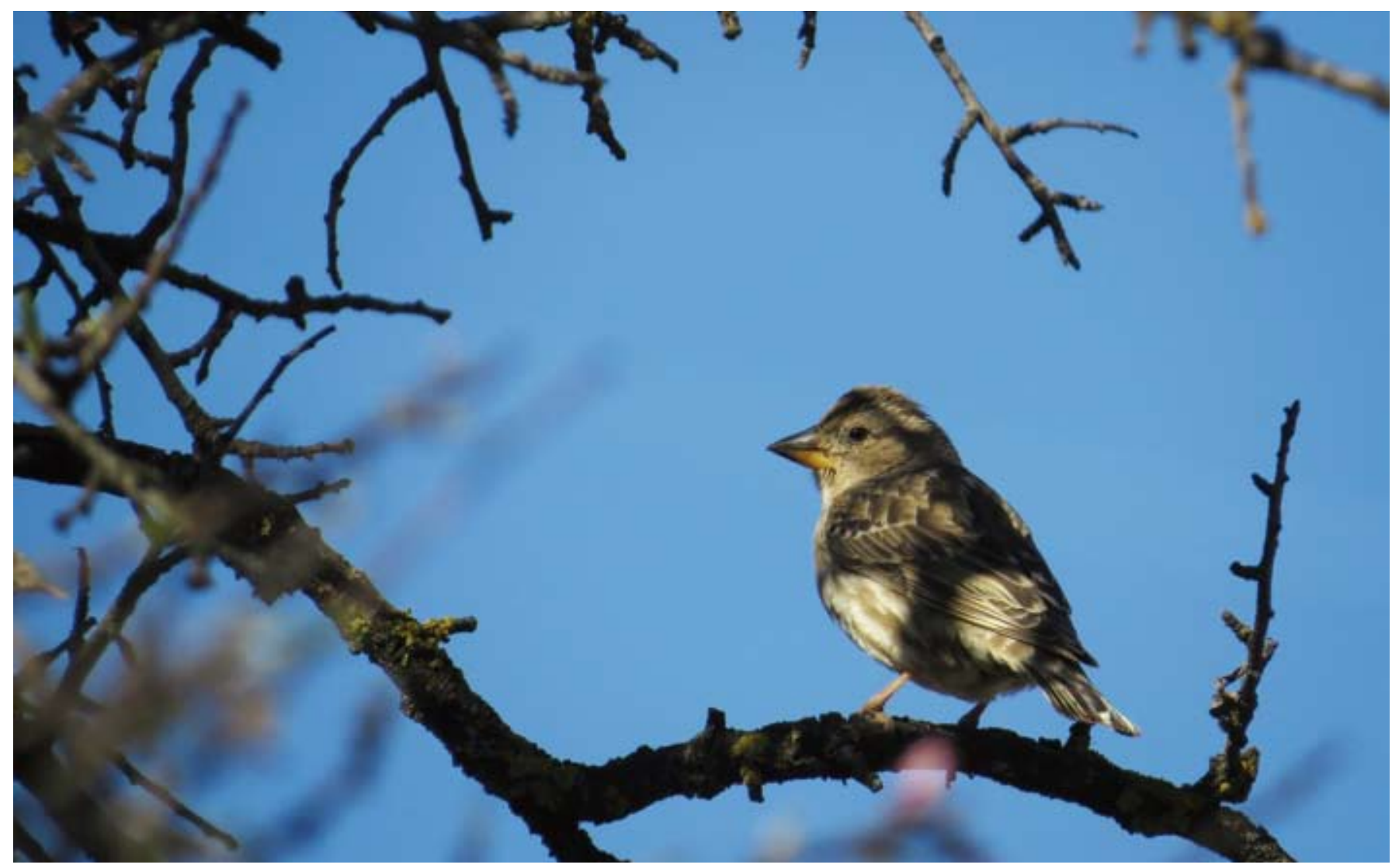

Fig. 1 - Male photographed on 2.4.2015 in the area A. Individuals that nest in almond trees cavities are present since the first decade of February. / Maschio fotografato il 2.4.2015 nell'area A. Gli individui che nidificano nelle cavità dei mandorli iniziano a frequentare l'area dalla prima decade di febbraio. (Photo / Foto Bruno Santucci). 




Fig. 2 - Mean flock size ( \pm standard error) and number of flock records per month in the entire study period. / Dimensioni medie dei gruppi ( \pm errore standard) e numero di osservazioni di gruppi per ogni mese nell'intero periodo di studio.

\section{Habitat use}

In the whole study area, Rock Sparrow winter flocks can be found between an altitude of 700 and $1100 \mathrm{~m}$ a.s.l. All the selected components are strictly related to the agricultural landscape of the area (Fig. 5) as detailed in the following paragraphs.

The most frequently used foraging habitats were Arable stubble $(17.71 \% \pm 4.72$ S.D. $)$ and Xerophilous pastures. Three other important environmental components were Autumn or Spring sowing fields $(14.00 \% \pm 3.67$ S.D.), Fallow lands (13.30\% \pm 3.16 S.D.) and Ploughings (10,30\% $\pm 3,61$ S.D). In $82.4 \%$ of the fields where Rock Sparrows used to feed, trees or bushes were present (Fig. 4). The elements

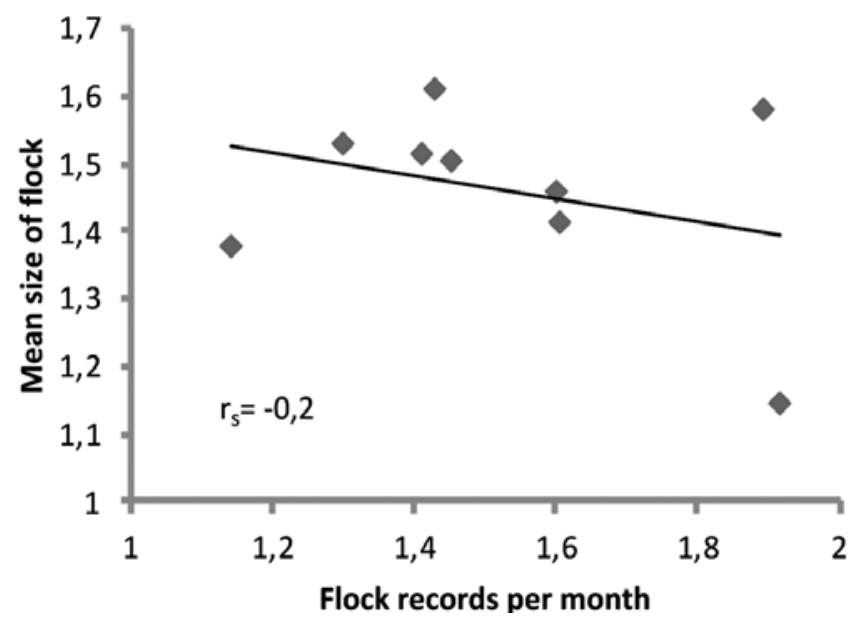

Fig. 3 - Flock records per month related to the mean size of flocks. The Spearman's rho correlation value is reported. / Numero di osservazioni dei gruppi per mese correlato alla dimensione media dei gruppi. Si riporta il valore della correlazione di Spearman rho.

without vegetation were covered respectively by Gravel roads $4.43 \% \pm 0.76$ (S.D.), by Heaps of pebbles $4.80 \%$ \pm 0.92 (S.D.) and by Farm depots $4.43 \% \pm 1.14$ (S.D.).

\section{Association with other species}

The flocks have been observed in association with 23 different bird species. The most common species was Tree Sparrow Passer montanus (14.2 \%), followed by Starling Sturnus vulgaris $(12.8 \%)$ and Crested Lark Galerida cristata $(9.6 \%)$. The frequency for each species is recorded in Tab. 1 and has been calculated on a total of 366 contacts in the entire study period.

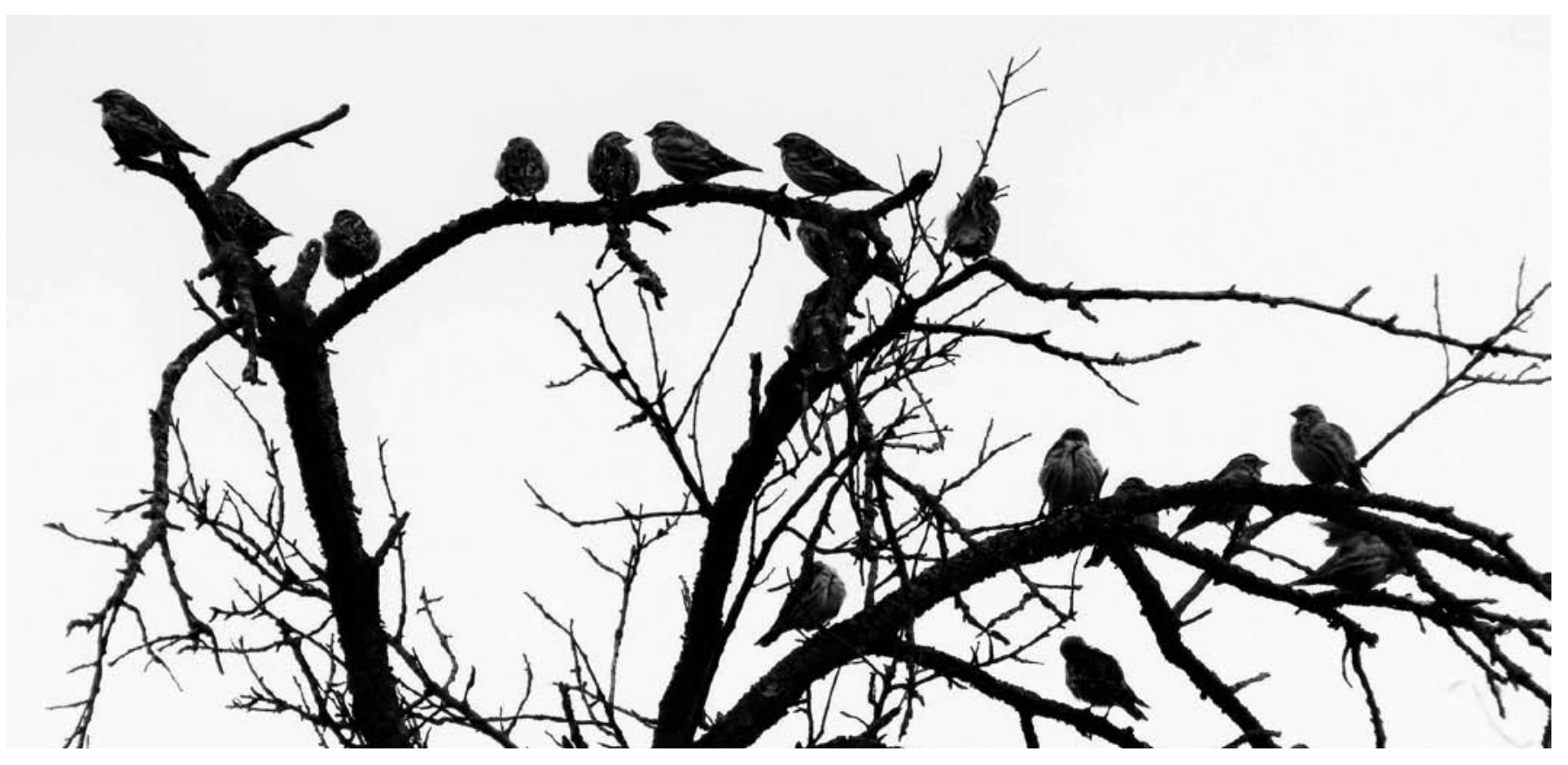

Fig. 4 - Group photographed on 5.10.2018 in the area A. Rock Sparrows feed in the fields and shelter on bushes when a predator is present. / Gruppo fotografato il 5.10.2018 nell'area A. L'attività trofica è svolta sui campi e gli individui si rifugiano sulle siepi in presenza di predatori. (Photo / Foto Bruno Santucci). 




Fig. 5 - Habitat use in Rock Sparrows in the study area. Percentage and standard error for habitat use are shown. / Uso dell'habitat della Passera lagia nell'area di studio. Si riportano la percentuale e l'errore standard per l'uso dell'habitat.

Tab.1 - Frequency of species observed in association with Rock Sparrow flocks (calculated on a total of 366 contacts in the entire study period). / Frequenza delle specie osservate in associazione con i gruppi di Passera lagia (calcolati su un totale di 366 contatti nell'intero periodo di studio).

\begin{tabular}{|l|c|}
\hline Species & Frequency \\
\hline Tree Sparrow & 0.142 \\
\hline Starling & 0.128 \\
\hline Crested Lark & 0.096 \\
\hline Chaffinch & 0.085 \\
\hline Corn bunting & 0.077 \\
\hline Linnet & 0.074 \\
\hline Italian Sparrow & 0.060 \\
\hline Cirl Bunting & 0.052 \\
\hline Greenfinch & 0.044 \\
\hline Rock Bunting & 0.044 \\
\hline Yellowhammer & 0.038 \\
\hline Hooded Crow & 0.033 \\
\hline Goldfinch & 0.033 \\
\hline European Serin & 0.025 \\
\hline Woodlark & 0.016 \\
\hline Skylark & 0.016 \\
\hline Meadow Pipit & 0.014 \\
\hline White Wagtail & 0.008 \\
\hline Feral Pigeon & 0.005 \\
\hline Blackbird & 0.003 \\
\hline Wood Pigeon & 0.003 \\
\hline Jackdaw & 0.003 \\
\hline Magpie & 0.003 \\
\hline
\end{tabular}

\section{Leaving the shelters}

The average hours of leaving the shelters varied depending on the month (Fig. 6) and was related to the daylight hours $\left(r_{s}=-0,9405\right)$, as can be seen in Fig. 7. The earliest time had been recorded in April at 5:15 a.m., while the latest time was recorded in December at 7:35 a.m. The interval between the first and last individuals' leaving the same shelter was small and rather constant during the study period, with just a little increase during October and November (Fig. 6).

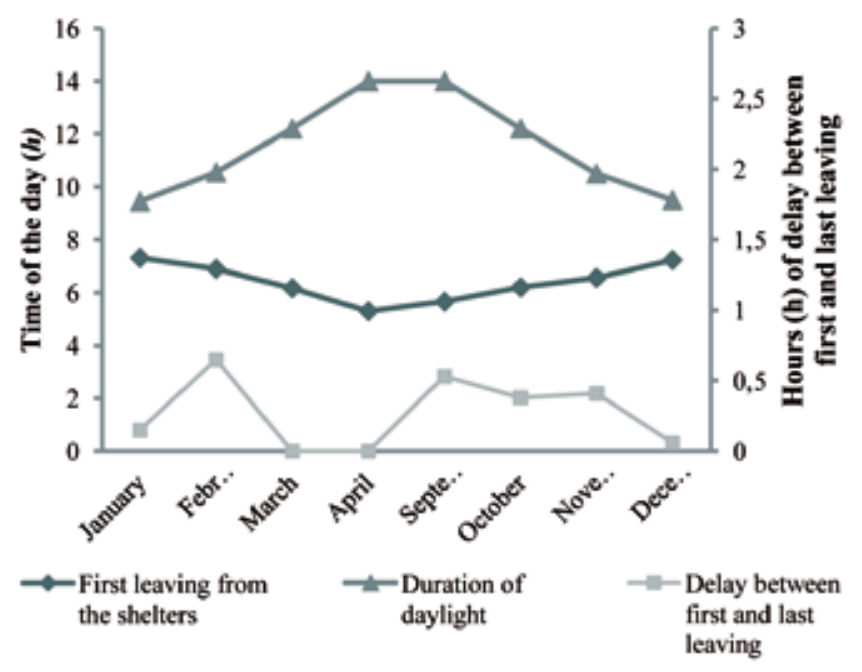

Fig. 6 - First leaving from the shelters (black diamonds) along the season compared to the hours of daylight during the day (dark grey triangles). Delay between first leaving and last leaving from the shelters (expressed in hours) is showed (light grey squares). / Prima uscita dai ricoveri (rombi neri) durante la stagione confrontata con le ore di luce durante il giorno (triangoli grigio scuri). Si riporta il valore del ritardo (espresso in ore) tra la prima uscita e l'ultima uscita dai ricoveri (quadrati grigio chiaro).

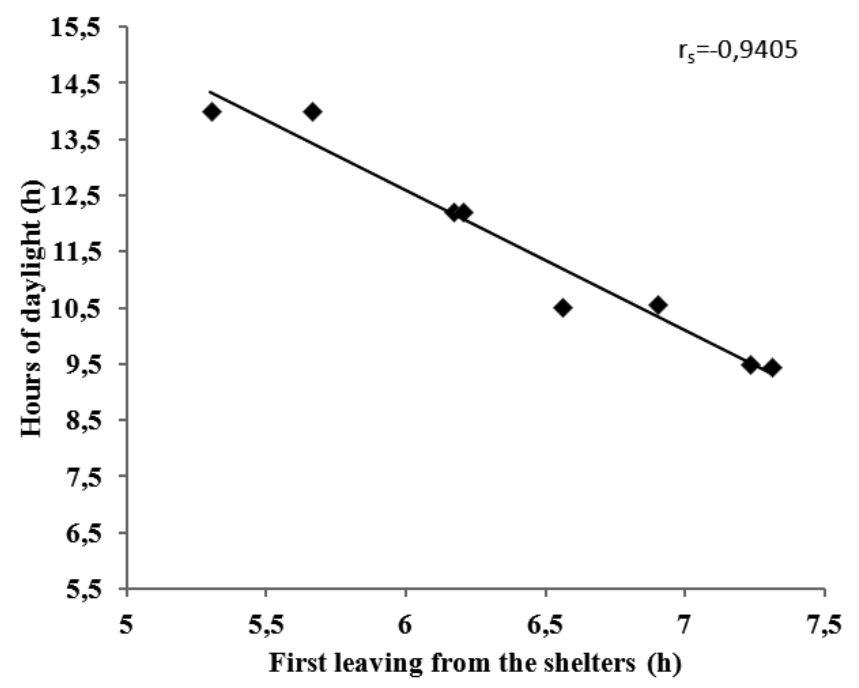

Fig. 7 - Relation between the first leaving of the shelters (expressed in hours) and the total amount of daylight hours during the day. The Spearman's rho correlation value is reported. / Correlazione tra la prima uscita dai ricoveri (espresso in ore) e il numero di ore di luce del giorno. È riportato il valore della correlazione di Spearman rho. 




Fig. 8 - Last return in the shelters (black diamonds) along the season compared to the time of daylight (light grey squares) during the day. / Ultimo rientro nei ricoveri (rombi neri) durante la stagione comparato con le ore di luce (quadrati grigi chiari) durante il giorno.

\section{Return to the shelters}

The trend of the average hours of evening returns to the shelters was similar to the trend of the leaving hours and was similarly related to the daylight hours $\left(\mathrm{r}_{\mathrm{s}}=\right.$ 0.8810 ), so it varied according to the month and consequently to the hours of daylight (Fig. 8). The earliest time was recorded in December at 16:24 p.m., while the latest in April at 18.17 p.m. The maximum delay recorded between the first and the last return in the same observation session was $1.05 \mathrm{~h}$, while the minimum was $0.05 \mathrm{~h}$. The mean value was $0.43 \pm 0.34$ (S.D.) h.

\section{DISCUSSION}

In the study area, the species is present all year long, even though the size of the flocks (shown in Fig. 2) suggests the possibility that small groups from surrounding areas join the locally resident population, as reported for other wintering passerines species (Repasky \& Schluter, 1994). The recorded flocks are bigger during the coldest months (Jan-Feb; Fig. 1). The tendency to remain in the same breeding area, to form flocks of different size, as well as the habitat use do not differ from the Catalan population (Baucells \& Abella, 2007, range size flocks: 30-150). In fact, the Rock Sparrow can be considered substantially sedentary, with movements limited within a range of a few kilometres (Brichetti \& Fracasso, 2013, movement range up to $150 \mathrm{~km}$ ), and with post-breeding dispersal movements (Summers-Smith, 2018). Association with other species has also been studied (Baucells \& Abella, 2007); the most important species quoted in literature (Tree Sparrow, Chaffinch and Cirl Bunting) are also included among those most frequently associated to Rock Sparrows in the present study, which further highlights the common association of Starlings and Crested Larks with sparrows. The most frequently used agricultural habitats, i.e. the Stubble and Bare Soils, are the same found as important in other studies focused on wintering passerines (Hancock \& Wilson, 2003; Garcia \& Whittingham, 2012). This underlines the importance of correct agricultural management for the conservation of Rock Sparrow populations. Trees and bushes on the field edges, which frequently characterize the sites used by Rock Sparrows, are presumably important because they are used as shelters in case of attack by predators. Rock Sparrows have also been reported laying eggs, defecating, preening and feeding on the trees, further underlining the importance of trees in the habitat where this species is present (Brichetti \& Fracasso, 2013). In fact, Almond trees have an important role as food resources during the period before and during flowering; in this period, we observed Rock Sparrows feeding on buds and flowers. The choice to feed on Cereal crops in their first stage of development may be due to the higher nutritional values of sprouting seeds (Sibbald et al., 1962). Rock Sparrows use as shelters the same abandoned buildings that are used during the breeding period, even though they were observed in clay tiles holes different from those where they built their nests (Brunelli et al., 2013; Santucci et al., 2017). We also noted that the species uses cavities, and occasionally trees, as repairs during winter.

Morning leaving takes place gradually. Generally, an individual goes out and reaches a perch like a tree or a power line and starts to make repeated calls (Fig. 9). The others reach it gradually. This behaviour is probably due either to the social status and attractiveness of the bird that starts the movement as a leader, a phenomenon that has been studied in the Rock Sparrow (Tòth \& Griggio, 2011); alternatively, it could be related to its sexual attractiveness, as it has been discovered in other passerine species (Mateos-Gonzalez et al., 2011). This behaviour has been well documented also in the House Sparrow, where a solitary pioneer recruits other individual towards food sources with its calls (Elgar, 1986). In case of bad weather (rain or light snowfall), the group quickly flies away towards foraging areas, whereas with good weather, the birds stay around the building for 15-30 minutes doing preening, leaving and returning to the building, and making contact calls. In this case, it is possible to observe social behaviours like circular flights 30-50 metres above the soil, which are carried out by some individuals or the entire group. We did not make any observation during heavy snowfalls because the areas could not be reached.

The close relationship between the times of leaving and returning on one side, and the amount of daylight time on the other side, seems to confirm this species' predilection for bright environments (Brichetti \& Fracasso, 2013). In France, the distribution limit corresponds to the contour line of at least 2000 hours of sun daylight, apparently confirming the tendency of the species to prefer habitats unvegetated or with sparse vegetation (Brichetti $\&$ Fracasso, 2013). However, we observed that the presence of some trees at the borders of the fields plays an important role of protection from predators. 


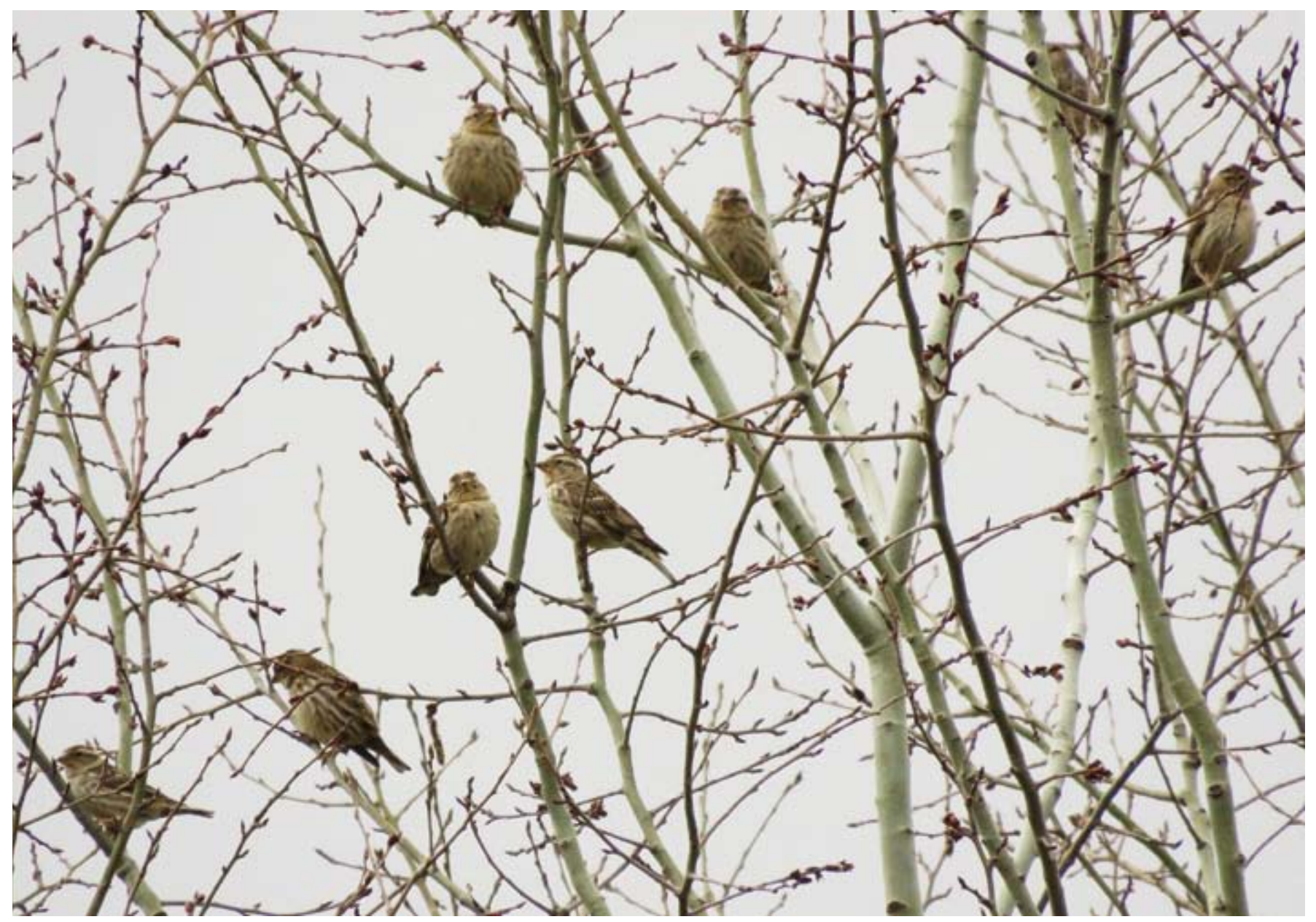

Fig. 9 - Group photographed on 22.1.2019 in the area A. Individuals leaving and returning to the shelters group together on roosts. / Gruppo fotografato il 22.1.2019 nell'area A. Gli individui all'uscita mattutina e prima del rientro serale si riuniscono sui posatoi. (Photo / Foto Bruno Santucci).

\section{Acknowledgements}

We are particularly grateful to Pietro Ramellini and Paul Harris for the assistance in the correction and revision of the manuscript, and Manlio Tiberi for the description of the agricultural crops and practice. Furthermore, we are grateful to two anonymous referees for their useful help and their useful suggestions.

\section{REFERENCES}

Baucells J. \& Abella J. C., 2007 - Les colònies de Pardal Roquer (Petronia petronia) a la comarca d'Osona: estat de la població i requeriments ecològics. Revista Catalana d'Ornitologia, 23: 1-9.

BirdLife International, 2017 - European Birds of Conservation Concern: Populations, Trends and National Responsibilities. BirdLife International, Cambridge, UK.

BirdLife International, 2018 - Species Factsheet: Petronia petronia. $<$ http://birdlife.org $>$ (downloaded on $1^{\text {st }}$ september 2018).

Brichetti P. \& Fracasso G., 2013 - Ornitologia italiana. Volume 8 Sturnidae - Fringillidae. Alberto Perdisa Editore, Bologna.
Brugerolle T., 2009 - Point sur la reproduction du Moineau soulcie (Petronia petronia) dans le Puy-de-Dôme en 2009. Le Grand-Duc, 75: 1-3.

Brunelli M., Miglio M. \& Santucci B., 2013 - Aspetti della nidificazione della Passera lagia Petronia petronia nella fascia pedemontana del Monte Velino (Abruzzo, Italia centrale). Uccelli d'Italia, 38: 7-12.

Elgar M. A., 1986 - The Establishment of Foraging Flocks in House Sparrow: Risk of Predation and Daily Temperature. Behavioural Ecology and Sociobiology, 19 (6): 433-438.

Garcia-del-Rey E. \& Whittingham M. J., 2012 - Habitat associations of wintering granivorous birds on the $\mathrm{Ca}$ nary Islands. Ornis Fennica, 89 (2): 130-138.

Garcia Navas V., Del Rincón A. G., Ferrer E. S. \& Fathi H., 2013 - Mating strategies, parental investment and mutual ornamentation in Iberian Rock Sparrows (Petronia petronia). Behaviour, 150: 1641-1663.

Guelin F., 2007 - La reproduction du Moineau soulcie (Petronia petronia) à La Sauvetat (63) en 2007. Le Grand-Duc, 71: 5-7.

Hancock M. H. \& Wilson J. D., 2003 - Winter habitat associations of seed-eating passerines on Scottish farmland. Bird Study, 50 (2): 116-130. 
Li S. \& Lu X., 2012 - Breeding biology of Rock Sparrows Petronia petronia in the Tibetan plateau, with special reference to life history variation across altitudes. Acta Ornithologica, 47 (1): 19-25.

Mateos-Gonzalez F., Quesada J. \& Senar J. C., 2011 Sexy birds are superior at solving a foraging problem. Biology Letters, 7 (5): 668-669.

Mingozzi T., Biddau L., Rinaldi F. \& Rosselli D., 1994 The Rock Sparrow Petronia petronia in the Western Alps: a multidisciplinary research programme. Atti del $6^{\circ}$ Convegno Italiano di Ornitologia (Torino, 8-11 ottobre 1991). Museo Regionale Scienze Naturali, Torino: 363-374.

Pace L. \& Tammaro F., 2006 - The Main Invasive Alien Plants in the Protected Areas in Central Italy (Abruzzo). In: Global Change and Protected Areas. Visconti G., Beniston M., Iannorelli E. D. \& Barba D. (eds.). Springer Science \& Business Media: 495504.

Petriccione B., 1993 - Flora e vegetazione del Massiccio del Monte Velino. Collana Verde n. 92. Ministero delle Risorse Agricole, Alimentari e Forestali, Roma.

Printemps T., 1992 - Notes sur le cycle annuel du Moineau Suolcie (Petronia petronia) a l'Abbaye de Fontevraud, Maine-et-Loire. Bulletin du Groupe Angevin d'étutes ornitologiques, 20 (43): 46-48.

Pulvirenti A. \& Santucci B., 2017 - Aspetti della biologia riproduttiva della Passera lagia Petronia petronia nel Lazio (Italia centrale). Alula, 24: 87-94.

Repasky R. R. \& Schluter D., 1994 - Habitat distribution of wintering sparrows along an elevational gradient: tests of the food, predation and microhabitat structure hypotheses. Journal of Animal Ecology, 63: 569-582.

RStudio Team, 2015 - RStudio: Integrated Development for R. RStudio, Inc., Boston, MA. <http://www.rstudio.com/>

Santucci B., Pulvirenti A. \& Miglio M., 2017 - Biologia riproduttiva e trend pluriennale di una popolazione di Passera lagia Petronia petronia in un'area dell'Appennino centrale (Abruzzo, Italia). Uccelli d'Italia, 42: 29-48.

Sibbald I. R., Slinger S. J. \& Pepper W. F., 1962 Sprouted, Frozen and Mouldy Wheats as Sources of Nutrients for Chicks. Poultry Science, 41: 10031004.

Summers-Smith D., 2018 - Rock Sparrow (Petronia petronia). In: Handbook of the Birds of the World Alive. del Hoyo J., Elliott A., Sargatal J., Christie D.A. \& de Juana E. (eds.). Lynx Edicions, Barcelona. $<$ https:// www.hbw.com/node/60955> (downloaded on $1^{\text {st }}$ september 2018).

Tavecchia G., Pradel R., Lebreton J. D., Biddau L. \& Mingozzi T., 2002 - Sex-biased survival and breeding dispersal probability in a patchy population of the Rock Sparrow Petronia petronia. Ibis, 144 (2): 79-87.

Tòth Z. \& Griggio M., 2011 - Leaders Are More Attractive: Birds with Bigger Yellow Breast Patches Are Followed by More Group-Mates in Foraging Groups. PLOS ONE, 6 (10): e26605.
Tottman D. R., Makepeace R. J. \& Hilary Broad, 1979 An explanation of the decimal code for the growth stages of cereals, with illustrations. Annals of Applied Biology, 92 (2): 221-234.

Venuto G., Tavecchia G., Taverniti E. \& Mingozzi T., 2005 - Effetti di variazioni termoclimatiche sui parametri riproduttivi di una popolazione alpina di passera lagia Petronia petronia. In: Boano G. et al. (eds.). Atti XIII Convegno Italiano di Ornitologia. Avocetta, (N. spec.) 29: 74 . 